\title{
The Culture Conflict between West and China Reflected in Idioms
}

\author{
Desheng Chen \\ School of Foreign Languages \\ Wuhan Polytechnic University \\ Wuhan, China 430023
}

\author{
Shuyin Lin \\ Student of School of Foreign Languages \\ Wuhan Polytechnic University \\ Wuhan, China 430023
}

\begin{abstract}
Idioms are those that are used in particular form, with a particular meaning, most widely used language. Idioms have a long history both in China and west. The different culture has bred the ethnic characteristics idioms, thus the use of idioms is deeply effected by the geographical environment, national characteristics, historical origin, religious beliefs, Can deeply reflect the contrast between Chinese and western idioms which contain the Chinese and western cultural differences. The study of the cultural differences between English and Chinese idioms can effectively avoid cultural differences so as to better use two kinds of language, and doing intercultural communication.
\end{abstract}

\section{Keywords-cultural conflict; idioms; influence}

\section{INTRODUCTION}

Idiom is a very important part in community which are established by usage after a long period's living of the local people, and it is also an important part of culture as the essence of it by reflecting one race's history, custom, spirit, characteristic and so on. Speaking with idioms will help people to rich their words and express themselves well. However if people do not master one cultural he or she may not use the idiom in the right way or even may misunderstand other people's meaning. As we know idioms is the outcome of one race, if we want the understand one idiom from other culture we need to study the culture background of it which will make us use it correctly and adequately. This is the reason why is so significant for us to study the idioms used in different countries and comparing their differences.

What's more with the development of technology people now live closer and closer in the little global village, communication with people from different countries and all kinds of culture is an undeniable trend, that is to say crosscultural communication become more and more important. Studying the idioms is a good way to learn different culture, so as to tackle the communication barrier.

The study of idiom from China and West has a significant meaning in cultural learning and cross-cultural communication. However the research in this aspect is not mature the reason is that only during recent twenty years

*Research Foundation: 2016 Wuhan Polytechnic University Humanities and Social Sciences Research Project (Project Number: 2016J09) more scholars began to focus on the field of folk-custom and contact this with the cross-culture communications research, but the recent researches always combine all idioms together without any logical and systematic convey and reasonable dispose. In this paper I will clear up the study in a more logical way, narrate it from the reason to its influence and express it with amount of specific idioms, by comparing many examples in two languages to prove my opinions.

\section{THE NECESSITY OF COMPARATIVE STUDY IN CHINESE AND WESTERN IDIOMS}

How do Chinese people understand the idiom "Love me love my dog"? As for the idiom some people may describe it as "If you love a person you may have feeling with the things that belongs to him" or "to show feelings for someone". Chinese may feel puzzled about the reason Why do the western people use "dog" to express the meaning? Is it shallow? Because in China "dog" is not a good word as what it is in west,which is usually used to express some bad things like "watchdog", "dogleg", "live a dog's life", "Dog's mouth spit no ivory", Chinese can no get the meaning of the "dog" used by western, which s usually expressed like "Every dog has his day", "as a dog with two tails", "be dog at something". These idioms reflect different culture and their specific lifestyle between Chinese and West. This is an obvious reason of the necessity of comparative study in Chinese and Western idioms.By comparative learning we can well understand other culture, for example we know the word "dog" is good image, comparing the "dog" in China we find that dogs are considered as the friend of people in west while in China their is a tradition of ask dog to guard the entrance. By comparing this we can not only get out of the communication barrier, but also get the associative meaning of the idiom or sentence with dog in china.

For the special production way, as the essence of culture Idiom is also a type of art, with great research value. Especially come idioms used by famous artists will enhance its value. William Shakespeare's works incarnate the values of art. The famous idiom "There's a special providence in the fall of a sparrow." comes from the great works The Hamlet which means "Everything is doomed". It surface meaning is "the sparrow's fate is clear", and Chinese who has not read the idiom may not get the point just take the words too literally. They may wander if they can change the 
"sparrow" to any other animal because they do not have the same life style like western people.So comparing the idioms between China and west is the key point to research the different views between Chinese and English cultures. Therefore, the idiom is observed as a shift from a linguistic approach to a cultural approach on the study.

The Idioms are influence by many factors that make it different between China and West.For example the different life-styles, geographic environment, historical cultures, religious beliefs and so on. Let's take the historical cultures as an example. The idiom "be born in the purple" means "the people born in a rich and powerful family". The meaning of "purple" in the idiom is "rich and power", which is the output of historical culture in western countries. Because in the ancient time the powerful people in Greece will wear in purple, later the "purple" is a representative of power in ancient Greece. While in ancient China people in power wore in "yellow", the color yellow is the symbol of power and rich.Because of the different historical culture people in different countries can understand each other by learning and comparing the cultural difference reflected in idioms. English and Chinese idioms carry cultural features and information of their nations and it is closely related to their cultural traditions. By comparing idioms from China and West according to the geography, religion, and history is a good way for us to learn other countries culture.

\section{THE REASON OF THE CULTURAL CONFLICT IN CHINESE AND WESTERN IDIOMS}

\section{A. The Reason of History}

It is a fact that idioms are closely related to history, which means that many idioms are originated from their own historical events which are well-known by the local people. For instance, China is a old country with more than five millennium, there a lot of idioms originated during the history the following idioms are from historical events in Ancient China: "Playing the Lute to a Cow" 对牛弹琴 In ancient times was a man who played the zither very well. Once, he played a tune in front of a cow, hoping that the cow would appreciate it. The tune was melodious, but the cow showed no reaction, and just kept on eating grass. The man sighed, and went away; "Blind man touching an elephant" 盲 人摸象 Once upon a time,some blind men met together. They heard about elephant, but could not imagine how it was like, so they decided to find a chance to touch the elephant. The chance came before long. The first man,only touching the teeth, said that the elephant was like a round stick.The second man, only touching the body, said that the elephant was like a wall.The third man, only touching the leg,said that the elephant was like a pillar. The fourth man, just catching the tail, shouted that the elephant was like a rope. They insisted their own idea and could not reach common understanding on how the elephant was like; Mao Sui Recommending Himself (毛遂自荐) In the Warring States Period, the State of Qin besieged the capital of the State of Zhao. Duke Pingyuan of Zhao planned to ask the ruler of the State of Chu personally for assistance. He wanted to select a capable man to go with him. A man called Mao Sui volunteered. When the negoti-actions between the two states were stalled because the ruler of Chu hesitated to send troops, Mao Sui approached him, brandishing a sword. At that, the ruler of Chu agreed to help Zhao, against Qin, "Drawing a snake and adding feet”画蛇添足: In the Southern and Northern Dynasties Period (420-589), there was a painter called Zhang Sengyou. Once he visited a temple and painted on the wall four dragons, but gave none of them eyes. The onlookers felt that this was odd, and asked why he hadn't painted the eyes. He answered, "Eyes are crucial for dragons. With the eyes painted on, the dragons would fly away." Nobody believed this, so Zhang Sengyou took up his brush and added eyes to two of the dragons. No sooner had he finished than the two dragons flew into the sky amid a thunderstorm. The two without eyes stayed painted on the wall; “So angry that one's hair lift up one's hat”怒发冲冠 In the Warring States Period, Lin Xiangru, chief minister of the State of Zhao, was sent as an envoy to the State of Qin to ask the ruler of Qin to return a fine piece of jade to Zhao. But the ruler of Qin was rude and unreasonable. Lin was angry, and his hair stood up so stiffly on his head that it lifted up his hat.

England does not have a history so long as China's, however there still many classical historical event happened and leave some idioms. for instance, "Hobson's choice" 别 无选择 There is a story that this expression comes from a Mr. Hobson who hired out horses and gave his customers no choice as to which horse they could take. This has all the credentials of a "folk etymology" myth but, in this case, the derivation is correct. A search of Google returns several thousand hits for "Hobbesian choice". The mistaken uses of that phrase, in place of the correct "Hobson's choice", originate from a confusion between the celebrated philosopher Thomas Hobbes (who, incidentally, was the originator of another commonplace phrase - 'nasty, brutish and short') and the less well-known carrier Thomas Hobson, to whom the phrase refers.“As mad as a hatter”疯狂 Mercury used to be used in the making of hats. This was known to have affected the nervous systems of hatters, causing them to tremble and appear insane. A neurotoxicologist correspondent informs me that "Mercury exposure can cause aggressiveness, mood swings, and anti-social behavior.", so that derivation is certainly plausible - although there's only that circumstantial evidence to support it.The use of mercury compounds in 19th century hat making and the resulting effects are well-established-mercury poisoning is still known today as 'Mad Hatter's disease'. That could be enough to convince us that this is the source of the phrase. The circumstantial evidence is rather against the millinery origin though and, beyond the fact that hatters often suffered trembling fits, there's little to link hat making to the coining of "as mad as a hatter".

There are too numerous historical idioms to be list literally, the examples above can strongly proof the influence of history on idioms.

\section{B. The Reason of Religion Belief}

Every country and race are influence by Religion by affecting people's life and belief, Amounts of idioms were originated from the development and evolution of religion. Different religions are popular in different countries, even 
people from the same country may believe in different religion.If we want to learn the influence of religion on idioms we should firstly learn the origin of the religion. Religion, is a kind of philosophy, and one of the ancestors of the unknown, to record and study of life, like the old testament, it was a jewish history textbook, if you want to know the culture of the jews, that you must go to research the book, on the other hand, if you want to learn Hebrew, this is a best textbook, at the same time of learning the language you can learn a lot about the culture and custom of the jews, for the same reason the Koran is the best book to learn Arabic, is also covers the entire Arab nation culture and dribs and drabs of life.So there many idioms in Bible are worthy to be study if we want to know the western culture.For example : “after one's own heart” 称心如意;正中 下怀. Derived from, the old testament of the bible, it is said that Israel's founding, Saul the king of Israel, but later he complacency and cause the displeasure of god, god commands judged Israel Samuel again made a new king. And Samuel said to Saul, "your throne will not be long now. The Lord has found a man of his liking, made him do the prince of the people, because you did not obey the Lord had commanded you; “A grain of mustard seed"一粒芥种: The kingdom of heaven is like a mustard seed, which a man took and sowed in his field.and so on. There are many other idioms with strong religious color. For example the "church" is the symbol of religion so there idioms like "take me to church", "as poor as the church's mouse" and so on.

Different from Britain, Taoist school and Confusion school are popular in China, Taoist School. Therefore the Taoist school and Confusion school have influence the Buddhist culture although which was originated from the other country. Through thousand of years evolution, Chinese culture has absorb the feature of the principals of Taoist school and Confusion school, which especially reflect in many idioms. For instance, the idiom "While the priest climbs a post, the devil climbs ten”道高一尺, 魔高一 丈 is used to warn the Buddhist disciples stand against the outside temptations, Now it means that 1 there is always at least one power stronger than the other. For another example, the zen proverb "Setting quietly, doing nothing, spring comes and the grass grows by itself 静坐无为春来草自生. This is also a life philosophy tell us do not pay too much attention or wait for something on purpose, things will happen naturally.

\section{The Reason of Geographical Environment}

One country's culture and human beings are closely related to the geographical environment, according to different geographical environment we have ocean civilization, river civilization, mountain civilization and so on. For example: Britain is an island country surrounded by ocean, which does not border on any other countries except the Republic of Ireland. This geographical advance made its marine industry well developed in the ancient time and British people have a strong feeling with water and their everyday lives are closely related to water. In a word it is the ocean that breed the British culture. While as for China, which is a big country with a large land area of more than 960sq.km, where people live on land. That is to say Chinese culture are closely related to land.This very geographical difference results in different idioms in the two languages. For example, there many idioms in china with word "land" like: “挥金如土”“卷土重来” “太岁头上动土”While as for Britain many idioms are related to "water", for instance, “able seaman”一级水平, “be left high and dry”陷于困境, “as weak as water”弱不经风, “to miss the boat”错失良机 and so on. Furthermore, by comparison we may have more deep impression as we know in china we have idioms like “挥金如 土” to express that someone waste money on trash, while in Britain we have idiom "spend water like money" to express this meaning.Take the other instance, in china we use the idiom '雨后春笋' to describe the new things cropping up in great numbers. Correspondingly, English have the idiom 'spring up like mushrooms' to tell the same meaning, since in china there are bamboos everywhere, while British people are familiar with mushrooms. There are still many examples can proof the fact that idioms are influenced by geographical environment.

\section{THE INFLUENCE OF THE CULTURAL CONFLICT IN CHINESE AND WESTERN IDIOMS}

\section{A. Influence of Rhetorical Device}

1) Metaphor: Although people in difference countries are deeply influence by the environment they live, however from the physiological perspective they are all human beings with similar thinking, which means that there are many cultural overlaps between the two cultures. For the reason, the idioms of Chinese and English are different, especially metaphoric idioms inevitable have a lot in common.

Here is an example, In Chinese we have an idiom “趁热 打铁" while in English we have an equivalent idiom "to strike while the iron is hot".This is almost one to one correspondence translation, why? Because both Chinese and English people have the impression of 热“hot"when we talk about the 铁 "iron". However, the difference exist in the use of metaphor in idioms, for example, the tenor and vehicle of metaphor in idioms of two cultures, in many cases, are quite different, which causes the difficulties in translation of metaphors in idioms.Here we classify the metaphor into two types: the first type: we call it Non-equivalence of metaphoric idioms which means that the target language has no direct equivalence for the tenor and vehicle of metaphor in idioms. Though many idioms in English and Chinese can be directly translated into each other,due to the undeniable difference between, the culture barrier still exist for us to find the totally equivalent idiom in another language. For example, the English idioms Achilles "Judas kiss" is an metaphor comes from the Creek mythology and we cannot find a direct equivalent image in Chinese language. Another type of metaphor we call it Misinterpretation, the meaning of which is that Some idioms always mislead the translators.We can not just get the meaning by its surface, and we can only get the right meaning by well understanding of one idiom's origin and inner meaning. For example, the idiom "take someone for a ride" means cheat someone in some way. 
However, this idiom lends itself easily to be misunderstood by the people who are not familiar with the idiom accepting the literal interpretation and neglecting the metaphoric meanings.

2) Similar: Similar is a well known rhetorical device in writing,however due to the culture difference between different languages, even the same implied meaning may be described in different metaphorical objects.

Let's take the words of animal as examples, In China the cattle is used to plough, cattle leave the impression of strength, so Chinese use “力大如牛” to describe some one has a lot of muscle and mustard as strong as a cattle, while in Britain people are more familiar with horse, because they use horse to plough, so they use "as strong as a bull " to describe the meaning. Another example, the dragon is the symbol of power in China, which is considered to be sacred and "a lion in the way”拦路虎 goose flesh 鸡皮疮㾂 as scared so there is a Chinese idiom “龙凤呈祥” to describe happiness, lucky and prosperity, as for the west "dragon" is a strange thing which is the mysterious, the symbol of bad things, totally distinct with what it is in China.

\section{B. 4.2 Influence of Image}

1) Equivalent: Some of the animal words in English and Chinese idioms appear strikingly similar or the even totally the same cultural characteristics.

For example: compare snail to slow worker "as slow as a snail"; compare bee to a hard working person "as busy as a bee"; use "cock" to describe some is arrogant "as proud as a cock"; use "pig" to describe someone is dirty and greedy; use "fox" to describe someone is "as sly as a fox"; use feather to describe something is "as light as a feather", etc.. During the evolution of human civilization, the universal feature exist in every race's life experience and ideological understanding, on account of which there many similarities in Chinese and British idioms.In addition we need to find the cultural exchange has also make great contribution to the development of idioms in every countries. The source of idioms are from three ways: the first is from the folk; the second is from the ancient time; the third is from the foreign countries, from these three origin we can get the conclusion that human civilization are improved and developed in the endless cultural communication.

2) Opposite image: Special human evolution leads to the human, though in the same process of evolution Presents different characteristics, because the nature where human existence, the environment where human live are Diversity. and the result of human to adapt to the environment are difference, make the human culture the colorful characteristics.

Comparing with the general of human cultural evolution the particularity of human cultural evolution are more common. For example: when describing be the burden to others, Chinese choose "Horse" while the English use the "sheep" (the black -the sheep of the family) instead; Describe achieve two goals with one action, Chinese say "一箭双雕" and "一石二乌" (to kill two birds with stone); Describe achieve different goals with different actions, Chinese say 缘 木求鱼 "climb a tree to look for fish", while English use" hen house looking for the rabbit" (seek a hare in a hen 's nest); Chinese People say "like a cat on hot bricks", English use "like a cat on hot bricks"to express anxiety; English have the expression of "crocodile tears", while the Chinese say" Cat crying mice" English "for the meaning; Describe life is miserable, the Chinese would say, "had a cow Horse is better than life "while English would say" lived the life of a dog that "(the to Live like a dog 's life). Culture and People's Daily life and customs always closely related.language, as one of the most important part of culture, is the objective reflection of culture. English and Chinese languages reflect different culture pattern and a breakthrough point and different perspective. Therefore, English and Chinese idioms on the use of the image have significant differences.

\section{CONCLUSION}

There is a profound relationship between language and culture, language is part of the culture, which is similar to the mirror of culture. The language of a nation reflects the form of numerous and complicated and colorful national culture. Rooted in two very different cultural background between English and Chinese, the two languages inevitably have a huge cultural difference.. Therefore, the cultural background become a vital factor, for the translator of foreign language learning and translation.As a successful translator , proficient in the two cultures are even more important than master two languages. Based on this perceive, we believe that a translator only to master two languages, configure a bilingual dictionary is not enough, the sensitivity to cultural differences between two languages and proficiency in crosscultural communication is undoubtedly their necessary quality.

\section{REFERENCES}

[1] Zhao Rongqing. on Cultural Differences between Chinese and English Idioms [J]. Western Development Magazine, 2012 (23)

[2] Yan ning. Cultural Differences and Translation of English \& Chinese Idioms [J]. Overseas English, 2012 (45)

[3] GU Nan. Analyze the Cultural Differences of Chinese and English Idioms and Translation Strategies [J]. Science \& Technology Information, 2009 (37)

[4] Zheng Mingwu . Culture Differences and the Translation of English and Chinese Idioms [J] . Science and wealth, 2014 (23)

[5] HE Su-Fang. On cultural differences and translation between Chinese and English idioms [J] . Journal of Minxi Vocational \& Technical College, 2008 (19)

[6] BS Zhao. On Culture Differences and Translation Techniques of English-Chinese Idioms [J] . Journal of Jishou University, 2006 (3)

[7] Yang min, Lei Lijuan, Zhai qiong . Influence of Context on Chinese and English Idioms Translation [J] . Overseas English, 2010 (27)

[8] G. Huang. A Brief Discussion on the Translation between Chinese and English Idioms fromJournal of Chongqing Three Gorges University [J] . 2012 (45)

[9] WU Jie. Discussion on the Cultural Differences between English and Chinese Idioms and the Method of Translation [J]. Journal of Changchun Finance College, 2013 (6) 